\title{
RELIEF HiSTORY AND COUPLING OF EROSIONAL Processes in the Teton Range, Wyoming
}

\author{
LISA TRANEL \ JAMES SPOTILA \ DEPARTMENT OF GEOSCIENCES \\ VIRGINIA TECHNICAL INSTITUTE $\downarrow$ BLACKSBURG
}

\begin{abstract}
$\uparrow \quad$ INTRODUCTION
Erosional processes influence topographic relief in mountain landscapes, but the spatial variation between differential processes and influence on tectonic uplift is poorly understood. Deep canyons and adjacent high peaks distinguish the Teton Mountains from nearby ranges, making it an ideal location to study how glacial, fluvial, and hillslope erosion interact to maintain high topographic relief. The purpose of this study is to quantify erosion rates of individual geomorphic processes in this complex system using a variety of techniques to see how each process contributes to landscape evolution in this mountain range.
\end{abstract}

To identify differential erosion throughout deep incised canyons we are using stream and moraine detrital apatite (U-Th) $/ \mathrm{He}$ thermochronometry, terrestrial cosmogenic radionuclides produced in surficial bedrock, and talus fan volumes and distribution to quantify the effects of glaciers, streams and mass wasting. Previous studies revealed that erosion is more effective in basins than summits, causing topographic relief to increase (Small et al., 1997). Yet, in purely fluvial systems, Stock et al. (2006) concluded that streams erode uniformly in small mountain catchments. We are interested in measuring how the efficiency of erosional processes evolves with changing climatic conditions. We hypothesize that substantial erosion occurred in the basins during the last glaciation, and continued erosion through fluvial and hillslope processes has maintained the high relief preserved in the Teton Range after glaciation. If these processes are not effectively eroding the bedrock, then the topographic characteristic of the Teton Range has been preserved since the last glacial event in the region.

The summits of the Teton Range vary from other Laramide and Basin and Range mountains. In ranges such as the Beartooth, Wind River, Front Range, and Sierra Nevada mountains, the peaks are more gently sloping (Small and Anderson, 1998). In the Teton Range, peaks are very rugged with steep slopes dipping into deep canyons. Laramide ranges formed as a result of compressional tectonics folding large layers of sedimentary rocks. The Teton Range shows evidence of this deformation in nearby sedimentary rocks. Fission track ages calculated from apatite fission tracks also indicated that the rocks were compressed and folded (Roberts and Burbank, 1993). The front of the Teton Range is now defined by a large normal fault, which originated at approximately the same time as Basin and Range extension began in the nearby region of the Western U.S. Since activation, $\sim 7 \mathrm{~km}$ of slip has caused the peaks to rise and the floor of Jackson Hole to subside. Earthquakes related to the Yellowstone Hotspot enhance the movement along the normal fault, which has been active in the last 10, 000 years (Byrd, 1995; Love et al., 2003; Roberts and Burbank, 1993). While the tectonic evolution of the Teton Range has been slightly different from other Laramide Ranges, it is unclear if these differences are the cause of topographic variations. 
Foster et al. (2007) modeled topographic characteristics of canyons within mountain ranges of the Northeastern Basin and Range, including the Teton Range. They compared hypsometry and along-canyon profiles and found that the landscape in the Teton Range is different from other ranges in the region. They suggested that this difference may reflect a response to climatic conditions. Hampel et al. (2007) modeled uplift on the Teton Fault and found that uplift likely increased as a result of deglaciation of the Yellowstone ice cap.

Three glacial advances incised deep canyons into the Teton Mountains. The first event is less well dated and occurred at approximately the same time as the Illinoisan advance in the Midwestern U.S. During the Buffalo event, glaciers advanced to their southernmost extent in Jackson Hole and left deposits which still remain on high divides which were not affected by later advances or alpine glaciers (de la Montagne, 1956; Elias, 1996; Fryxell, 1929). This event would have been the first glacial event to begin carving Ushaped canyons into the Teton Mountains. Previous to that glacial event, only fluvial canyons controlled the landscape within the range. The Munger, or Bull Lake, event occurred $\sim 140 \mathrm{ka}$. Ice sheets flowed south from the Yellowstone Plateau and filled Jackson Hole a second time. Glaciers continued to carve deep canyons and erode the front of the range (de la Montagne, 1956; Edmund, 1956; Elias, 1996). The Pinedale advance was the smallest advance within the basin. Ice from the north filled Jackson Hole and alpine glaciers spilled into Jackson Hole from the Teton canyons beginning $\sim 44 \mathrm{ka}$. The moraines trapped ice and meltwater forming lakes on the west side of Jackson Hole which are still preserved (de la Montagne, 1956; Edmund, 1956; Elias, 1996; Love et al., 2003).

The timing of glacial events in the Teton and Yellowstone region has been well recorded based on moraine and outwash deposits in Jackson Hole, but the glacial deposits only record the age of the maximum glacial extent. Although the glaciers began receding by those times, erosion at high elevations would have continued until the glaciers melted completely. Cosmogenic ages from moraines on the Yellowstone Plateau indicate that the Pinedale glacial maximum was reached by $\sim 14 \mathrm{ka}$ (Licciardi et al., 2001).

\section{$\downarrow$ METHODS}

To begin quantifying denudational processes we surveyed talus fans and collected bedrock and sediment in Garnet Canyon. We chose this canyon because the bedrock is mostly uniform within the catchment and it is adjacent to the highest peaks in the range. It also contains one of the remaining glaciers in the range.

We are evaluating mass wasting of canyon walls and ridges by observing characteristics and extent of talus fans. Last summer we started an inventory of talus fans in Garnet Canyon. We surveyed fan extent using a laser range finder to measure width and length of fans and place them on a geomorphic map. We also measured the slope of the bedrock walls directly above the apex of the talus fan to project the shape of the bedrock beneath talus deposits. We calculated volume based on the bedrock projection and fan height and width. With our geomorphic map, we calculated the area contributing material to the talus fans. The rate of erosion by mass wasting was calculated by dividing the total volume of talus fan debris by the contributing area and the time when glacial retreat began, $14 \mathrm{ka}$ (Licciardi et al., 2001).

To verify the erosion rates on ridges, we will compare our mass wasting rates to weathering on bedrock surfaces. We started collecting rock samples around Garnet Canyon for this purpose. The rates will be determined with in situ cosmogenic radionuclides (CRN) ${ }^{10} \mathrm{Be}$ and ${ }^{26} \mathrm{Al}$. Rocks exposed at the surface experience a bombardment of cosmic rays from the sun producing ${ }^{10} \mathrm{Be}$ and ${ }^{26} \mathrm{Al}$ in quartz grains. The concentration of these isotopes increases with time if the rock is continuously exposed, therefore a measurement of isotopes present in quartz grains can approximate the exposure age of the rock (Nishiizumi et al., 1993). We have started extracting quartz grains from rock samples by crushing and separating the minerals. The samples will be sent to the University of Edinburgh in Scotland to complete the mineral extraction and measure the concentration of ${ }^{10} \mathrm{Be}$ with accelerator mass spectrometry (AMS). In a previous study in the region, Nishiizumi et al. (1993) collected one rock from the peak of the Grand Teton. They calculated an erosion rate of $0.048 \mathrm{~mm} / \mathrm{yr}$ in the Teton Range based on a single CRN exposure age. With our samples, we 


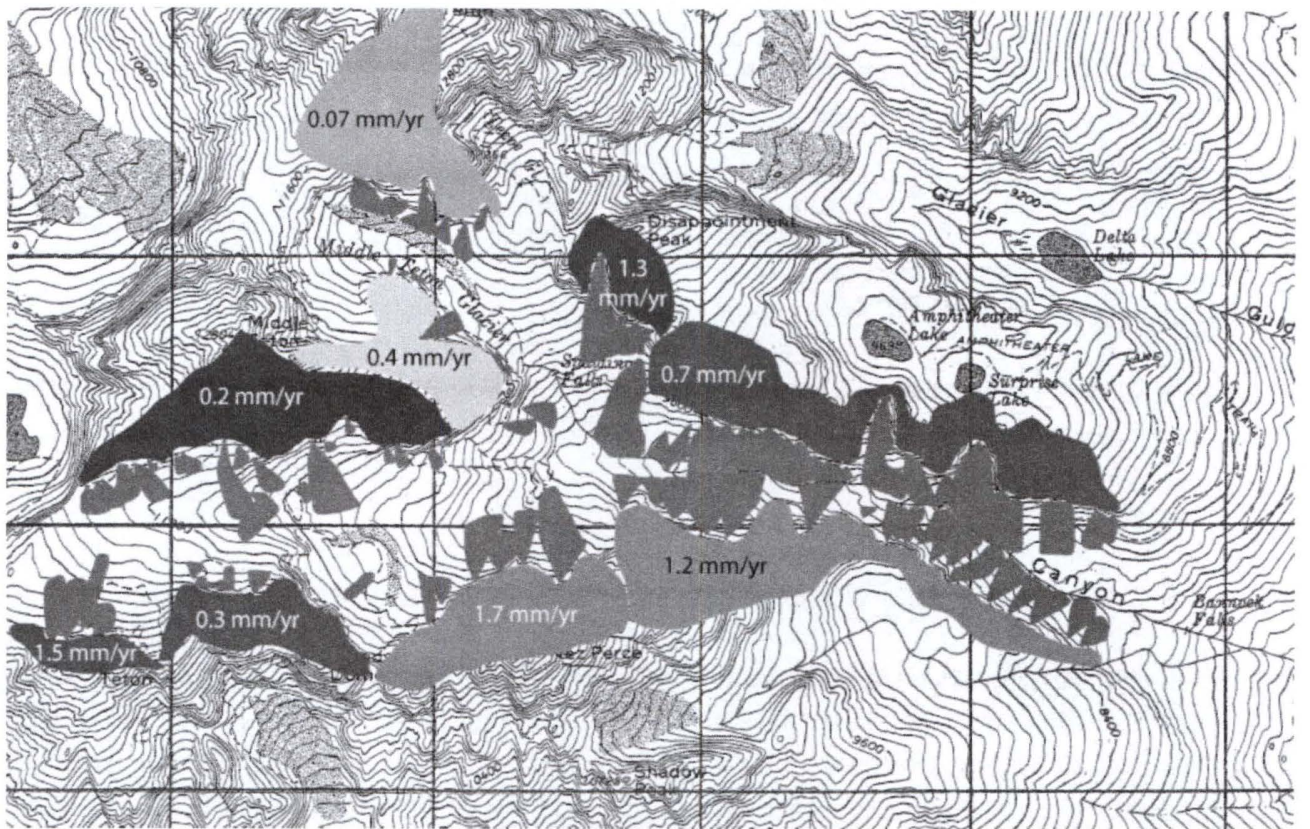

Figure 1. Talus fans and contributing bedrock areas are marked in this preliminary geomorphic map. Numbers represent mass wasting erosion rates for the surrounding bedrock area. Areas below the bedrock without numbers show the extent of the talus deposits.

hope to test if this rate is consistent around the rest of the canyon and in other locations in the range

In order to determine the spatial distribution of erosion we are using detrital apatite (U-Th)/He thermochronometry ( $\mathrm{AHe})$. This technique determines the age of individual apatite grains and compares the distribution of ages to a hypsometric analysis of topography. This method was developed by Brewer et al. (2003) and Ruhl and Hodges (2005) and applied by Stock et al. (2006) with $\mathrm{AHe}$ thermochronometry in the Sierra Nevada Mountains. AHe thermochronometry measures the concentration of uranium, thorium, and helium in apatite grains. Before tectonic uplift, rocks located deep in the crust experienced temperatures greater than $70^{\circ} \mathrm{C}$. At these temperatures, uranium and thorium decay and helium is completely diffused outside of the apatite grain. As rocks exhume and cool, helium is trapped within the apatite grain, providing a record of time since cooling began (Ehlers and Farley, 2003). We collected rocks along a $1200 \mathrm{~m}$ vertical transect to determine the range of ages in these mountains and to verify that ages increase linearly with elevation. We determined hypsometry of the catchment in Garnet Canyon using GIS (Geographical Information Systems). The next step is to combine the hypsometry with age-elevation gradient to predict sediment age distribution. The product is a probability distribution function or PDF (Brewer et al., 2003; Ruhl and Hodges, 2005; Stock et al., 2006), which predicts what erosion should be if erosion is uniform throughout the entire catchment. We are using this method to analyze stream and glacial sediment to see how age distributions vary during glacial and interglacial periods.

We are also testing fluvial erosion rates with a catchment-wide measurement using the CRN method mentioned above applied to stream sediments collected at the mouth of canyons. Quartz grain ages collected from streams are integrated to get an average of canyon-wide erosion rates (Binnie et al., 2006; Nishiizumi et al., 1993). We collected sediments from Garnet Canyon and Cascade Canyon streams to test variability of rates between these two canyons.

\section{$\downarrow \quad$ Results}

We calculated the volume of talus fan debris and used this information to calculate canyon-wide erosion rates due to mass wasting processes. The total volume is $1.6 \times 10^{7} \mathrm{~m}^{3}$. The canyon-wide accumulation rate is $1.42 \mathrm{~mm} / \mathrm{yr}$ 
and the erosion rate is $0.76 \mathrm{~mm} / \mathrm{yr}$. These results indicate that post-glacial hillslope erosion is keeping pace with estimated uplift of these mountains, which is $\sim 2 \mathrm{~mm} / \mathrm{yr}$ (Byrd and Smith, 1991; Hampel et al., 2007; Machette et al., 2001). We also notice spatial variability in the rates of mass wasting within the canyon (Figure 1). Rates are higher at lower elevations in the canyon than at the higher elevations. This could result from gradual deglaciation over time. The glaciers at the higher elevations were distributing the mass wasting debris away from where it was deposited more recently since the glacial extent has gradually decreased. Since this method only measures one process over a relatively short time scale we can see that the system is not in equilibrium and mass wasting is contributing to the Teton landscape. This is expected since the rock is highly jointed with many precariously positioned rocks hanging over steep walls. We cannot determine the long-term relief history with this method, so results from CRN analyses will provide important additional data.

We dated 5 bedrock samples from Garnet Canyon and 50 individual apatite grains from one Garnet Canyon stream deposit. The bedrock does show a linear increase in age with elevation (Figure 2). The distribution of grain ages shows erosion is concentrated at lower and higher elevations (Figure 3 ) than predicted.

There are two possible explanations for higher erosion at lower elevations. One reason could be explained by sediment transport. There are places in the canyon where sediment may be trapped. If this is the case, then the only sediments making it to the base of the canyon came from elevations lower than that of the trap. We did observe some areas where flow was slowed by talus debris and glacial deposits to form small, natural dams. The second explanation could be that fluvial erosion is more effective at these lower elevations.

Higher than predicted ages could indicate that the higher elevations are unstable, so erosion is high; or we have anomalous grains resulting from poor apatite quality. We did date some grains that must be anomalous because the ages were older than our oldest bedrock sample. These anomalous ages may result from inclusions of zircon or zoning within the apatite grains. These factors may increase the concentrations of uranium, thorium, and helium to give artificially older ages.

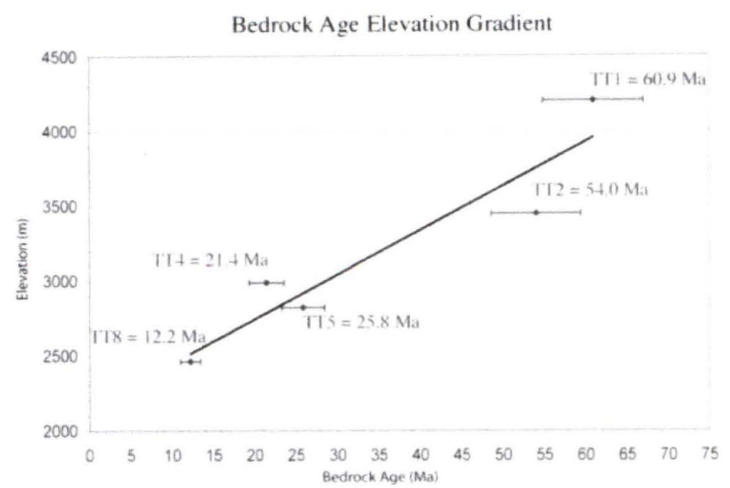

Figure 2. Age-elevation gradient for bedrock collected in Garnet Canyon. More rocks will be analyzed to fill in gaps in this line.

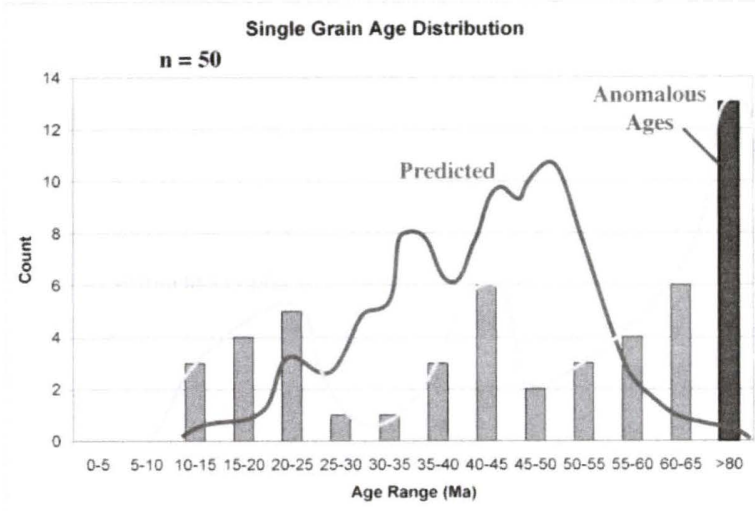

Figure 3. Single ages show concentration of erosion at higher and lower elevations. Since we have observed some inclusions and zoning in apatite grains, some ages may be anomalously old, indicating that they may be distributed among the younger ages beneath the predicted curve.

Since $\sim 20 \%$ of the grains have anomalously old ages, we looked at grains a little more closely. If apatite crystals have inclusions or zones, the amounts of uranium and thorium are not uniform within a single grain. To test how the quality may affect the results of our study, we have analyzed individual grains with scanning electron microscopy (SEM) and cathodoluminescence (CL) at Virginia Tech. So far, $\sim 12 \%$ of the apatite grains in the sediment had inclusions containing zircon and $26 \%$ of the grains had zoning. Zircon inclusions add helium, which would interfere with the apatite age. Zoning may affect our measurements since we assume that concentrations of uranium and thorium are uniform in the mineral, and age calculations are dependent on the grain size. Our next step is to analyze our bedrock samples with the same techniques to see if all bedrock contains poor quality grains, or if these grains are only 
coming from a few rocks within the catchment. We will continue to date additional grains to get a statistically significant number of individual valid ages. We will also date moraine sediments to compare the erosion patterns in the glacial and fluvial systems.

\section{$\downarrow$ SUMMARY}

So far, we see that recent mass wasting has been caused by jointing and low rock mass strength, which has enabled rapid hillslope denudation. The rate of hillslope erosion is comparable to long-term uplift rates. We will continue to study the effect of these processes by directly measuring ridge denudation with cosmogenic radionuclides in quartz minerals.

Detrital thermochronometry is indicating that post-glacial erosion is not uniform and excess sediments are sourced from low elevations. The apatite quality may affect the distribution of ages, so more apatite grains will be dated as well as studied with various techniques to see how significant these anomalous grains are throughout the canyon.

Overall, we see that erosional processes are fluctuating spatially and temporally, leading to non-uniform denudation at a given time. Yet when integrated over the long term, interacting denudational processes may balance tectonic rock uplift and maintain high topographic relief between glacial and interglacial periods.

\section{$\downarrow$ Literature Cited}

Binnie, S. A., W.M. Philips, M.A. Summerfield and L.K. Fifield. 2006. Sediment mixing and basin-wide cosmogenic nuclide analysis in rapidly eroding mountainous environments Quaternary Geochronology. 1:1-14.

Brewer, I. D., D.W. Burbank and K.V. Hodges. 2003. Modeling detrital cooling-age populations: insights from two Himalayan catchments: Basin Research. 15(3): 305-320.
Byrd, J. O. D., 1995. Neotectonics of the Teton Fault, Wyoming [Doctor of Philosophy thesis]: The University of Utah.

Byrd, J. O. D., and R.B. Smith. 1991. Geodetic evidence for aseismic reverse creep across the Teton fault, Teton Range, Wyoming: Geophysical Research Letters. 18(6): 1083-1086.

de la Montagne, J., 1956. Review of glacial studies in Jackson Hole, in Wyoming Geological Association 11th Annual Field Conference, Jackson Hole. p. 2932.

Edmund, R. W., 1956. Resume of structures and physiography in the Northern Teton Mountains, Wyoming, Wyoming Geological Association Guidebook 11th Annual Field Conference: Casper, WY, Wyoming Geological Association. p. 151-157.

Ehlers, T. A. and K.A. Farley. 2003. Apatite (UTh)/He thermochronometry: methods and applications to problems in tectonic and surface processes: Earth and Planetary Science Letters. 206: 1-14.

Elias, S. A., 1996. The ice-age history of National Parks in the Rocky Mountains: Washington, Smithsonian Institution Press. $170 \mathrm{p}$.

Foster, D., S.H. Brocklehurst and R.L. Gawthorpe. 2007. The Glacial Buzzsaw in the Northern Basin and Range: the Importance of Glacier Size and Uplift Rates: Eos, Transactions, American Geophysical Union, 88 Fall Meeting Suppl. Abstract H53C-1378.

Fryxell, F. 1929. Glacial Features of Jackson Hole, Wyoming: University of Chicago. $128 \mathrm{p}$.

Hampel, A., R. Hetzel and A.L. Densmore. 2007. Postglacial slip-rate increase on the Teton normal fault, northern Basin and Range Province, caused by melting of the Yellowstone ice cap and deglaciation of the Teton Range? Geology. 35(12): 1107-1110. 
Licciardi, J. M., P.U. Clark, E.J. Brook, K.L. Pierce, M.D. Kurz, D. Elmore, P. and Sharma. 2001. Cosmogenic $3 \mathrm{He}$ and $10 \mathrm{Be}$ chronologies of the late Pinedale northern Yellowstone ice cap, Montana, USA. Geology. 29(12): 1095-1098.

Love, J. D., J.C. Reed Jr. and K.L. Pierce. 2003. Creation of the Teton Landscape, A Geologic Chronicle of Jackson Hole and the Teton Range: Moose. WY. Grand Teton Natural History Association.

Machette, M. N., K.L. Pierce, J.P McCalpin, K.M. Haller and R.L. Dart. 2001, Map and data for Quaternary Faults and Folds in Wyoming.

Nishiizumi, K., C.P. Kohl, J.R.. Arnold, R. Dorn, J. Klein, D. Fink, R. Middleton and D. Lal. 1993. Role of in situ cosmogenic nuclides ${ }^{10} \mathrm{Be}$ and ${ }^{26} \mathrm{Al}$ in the study of diverse geomorphic processes: Earth Surface Processes and Landforms. 18: 407-425.

Roberts, S. V. and D.W. Burbank. 1993. Uplift and thermal history of the Teton Range (northwestern Wyoming) defined by apatite fission-track dating: Earth and Planetary Science Letters. 118: 295309.
Ruhl, K. W., and K.V. Hodges. 2005. The use of detrital mineral cooling ages to evaluate steady state assumptions in active orogens: An example from the central Nepalese Himalaya: Tectonics. 24: TC4015-.

Small, E. E. and R.S. Anderson. 1998. Pleistocene relief production in Laramide mountain ranges, western United States: Geology. 26(2): 123-126.

Small, E. E., R.S. Anderson, J.L. Repka and R.C. Finkel. 1997. Erosion rates of alpine bedrock summit surfaces deduced from in situ $10 \mathrm{Be}$ and 26Al: Earth and Planetary Science Letters. 150: 413425.

Stock, G. M., T.A. Ehlers and K.A. Farley. 2006. Where does sediment come from? Quantifying catchment erosion with detrital apatite (U-Th)/ Hethermochronometry. Geological Society of America. 34(9): 725-728. 